\title{
Interactive comment on "Seasonal contrast in size distributions and mixing state of black carbon and its association with PM1.0 chemical composition from the eastern coast of India" by Sobhan Kumar Kompalli et al.
}

Sobhan Kumar Kompalli et al.

sureshsplvssc@gmail.com

Received and published: 15 December 2019

Interactive comment on "Seasonal contrast in size distributions and mixing state of black carbon and its association with PM1.0 chemical composition from the eastern coast of India" is uploaded in the form of supplement

Please also note the supplement to this comment: https://www.atmos-chem-phys-discuss.net/acp-2019-376/acp-2019-376-AC1supplement.pdf 
Interactive comment on Atmos. Chem. Phys. Discuss., https://doi.org/10.5194/acp-2019-376, 2019.
ACPD

Interactive

comment 